\title{
Effect of Super White Washing Process Temperature and Optical Brightening Agent Concentration on Various Properties of Stretch Denim Fabric
}

\author{
Md. Zayedul Hasan, A. K. M. Ayatullah Hosne Asif*, Md. Tareque Rahaman, Sumaiya Akter \\ Department of Textile Engineering, Mawlana Bhashani Science and Technology University, Santosh, Tangail, Bangladesh \\ Email address: \\ ayatasif.mbstu@gmail.com (A. K. M. A. H. Asif) \\ ${ }^{*}$ Corresponding author \\ To cite this article: \\ Md. Zayedul Hasan, A. K. M. Ayatullah Hosne Asif, Md. Tareque Rahaman, Sumaiya Akter. Effect of Super White Washing Process \\ Temperature and Optical Brightening Agent Concentration on Various Properties of Stretch Denim Fabric. International Journal of Systems \\ Engineering. Vol. 5, No. 1, 2021, pp. 43-50. doi: 10.11648/j.ijse.20210501.16
}

Received: May 4, 2021; Accepted: June 1, 2021; Published: June 9, 2021

\begin{abstract}
This research work was intended to discover the effect of super white washing process temperature and OBA (optical brightening agent) concentration on various properties of stretch denim fabric. Different properties like tensile strength, tear strength, dimensional stability, pilling resistance, hand feel performance, color fastness to washing, color fastness to perspiration, color fastness to light were investigated. All experimental tests were carried out according to the ISO (International Organization for Standardization) standards. Stretch denim fabric treated with super white washing process demonstrated better results regarding tensile strength, tear strength and dimensional stability for $35^{\circ} \mathrm{C}$ temperature and $30 \mathrm{~g} / \mathrm{L}$ OBA concentration along with illustrated moderate to good ratings in different color fastness properties after gradual increase of processing OBA concentration and temperature; although no significant change was observed regarding the grade of color change and color staining for color fastness to wash, color fastness to perspiration and color fastness to light with respect to stretch denim fabric treated with super white washing. The grade for pilling resistance and hand feel performance was comparatively good after the elevation of processing temperature and OBA concentration. The GSM (gram per square meter) of stretch denim fabric also changed accordingly after increasing the OBA concentration and washing process temperature for super white washed stretch denim fabric. The dimensional stability of stretch denim fabric also altered after going through different OBA concentration and washing process temperature.
\end{abstract}

Keywords: Super White Wash, Temperature, Optical Brightening Agent (OBA), Stretch Denim, Tensile Strength

\section{Introduction}

It goes without saying that, no other fabric in this fashion world has been granted such widespread acceptance of denim among textile products [1-3]. Denim fashion is now widely used by individuals of all ages, classes and genders [4]. Technically, denim is a strong and durable fabric made from cotton [5-7]. Denim is woven with indigo-dyed warp and white filling yarn. Still denim has an immense influence on customers and is considered a manifestation of young people's individuality, a sign of antagonism and an attitude towards life [8]. The most common outfits in the fashion industry are denim clothing. Denim products have been widely recognized to significantly influence consumers' way of entity since they were invented [9, 10]. Denim also has changed its appearance from traditional work-wear to casual clothing to the first wear and functional consumption [11, 12]. In reality, Denim is a stiff and gloomy blue element without even any mode of attraction but washing is the groundbreaking mechanism that has transformed the global denim illustration [13-15]. A lot of factories and clothing brands involved in manufacturing of denim garments are continuously searching for new and exclusive features; so that denim manufacturing industries and design houses continuously seek for different and innovative styles [16]. Various washing processes associate with denim apparel are now be considered as an 
essential technique for manufacturing such kind of fashion apparel; apart from super white washing method, there are now countless variations exists $[17,18]$. Different washing techniques play a significant role to produce uniform color fading or vintage effects, depending on demand specifications $[19,20]$. Previously only washable blue and black jeans were associated for textile processing. Washing of garments is a technique introduced by manufacturers in order to provide such a product that satisfies the requirements of the customer [21, 22]. Today artificial wrinkles, special effects even more comprehensive treatments for apparel production are presently available [23]. Denim fashion was the beginning of today's clothing production, but to date, the most important aspect of this industry still is jeans washing [24]. To achieve the environmentally-friendly aspects of denim manufacturing become an increasingly important challenge for manufacturers and technologists [25-27]. Moreover, denim washing processes also have strong environmental and sustainable effects, which is well established in terms of minimizing or removing almost all of the constraints regarding manufacturing and processing that ultimately reduce water use, electricity, time and harmful substances [28-30]. In the blue region of the visible spectrum, natural fibers typically absorb more light because of impurities and particulates [31-33]. Such kind of circumstances lead to the unpleasant yellowish appearance of natural fibers; whereas this context is not so obvious in the case of synthetic fibers [34]. So that, whiteness appearance can be enhanced upon these substrates by intensifying the whiteness or color of the material by the intervention of optical brightening agents. The presence of an optical brightening agent also intensifies the coloration of dyed textile products $[35,36]$. Therefore, this exploration about the effect of super white washing process temperature and optical brightening agent on various properties like tensile strength, tear strength, dimensional stability to washing, color fastness to washing, color fastness to perspiration, color fastness to light, successive changes in fabric GSM for stretch denim fabric will surely come up with to improve opportunities for further study on denim washing. Overall, to determine the consequences of washing process temperature and OBA concentration on various aspects of stretch denim fabric treated with super white washing process was the principal purpose of this research work.

\section{Materials and Methods}

\subsection{Materials}

\section{Fabric}

$97.80 \%$ of cotton $2.2 \%$ of elastane indigo dyed stretch denim fabric was used for this research. The fabric GSM (gram per square meter) was 340 (Before wash), 3/1 twill fabric; width 57 inch.

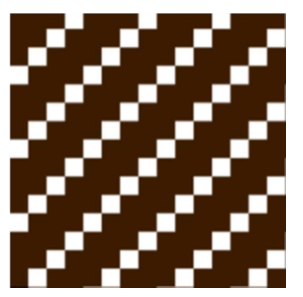

Figure 1. 3/1 twill fabric design RHT.

\section{Chemicals}

DENIMCOL Wash-RGN (desizing agent), caustic soda $(\mathrm{NaOH})$, Hydrogen Peroxide $\left(\mathrm{H}_{2} \mathrm{O}_{2}\right)$, Soda Ash $\left(\mathrm{Na}_{2} \mathrm{CO}_{3}\right)$, detergent, wetting agent, optical brightening agent (OBA), Acetic Acid $\left(\mathrm{CH}_{3} \mathrm{COOH}\right)$, DENIMCOL-N (enzyme) were used for this study.

\section{Experimental Instruments}

Washing machine, hydro extractor machine, tumble dryer machine, fabric touch tester, fabric GSM cutter, perspirometer perspiration tester for testing the color fastness to perspiration, electronic balance and fabric $\mathrm{pH}$ meter were also used for this research.

\subsection{Methodology}

\subsubsection{Working Flow Diagram of Super White Wash}

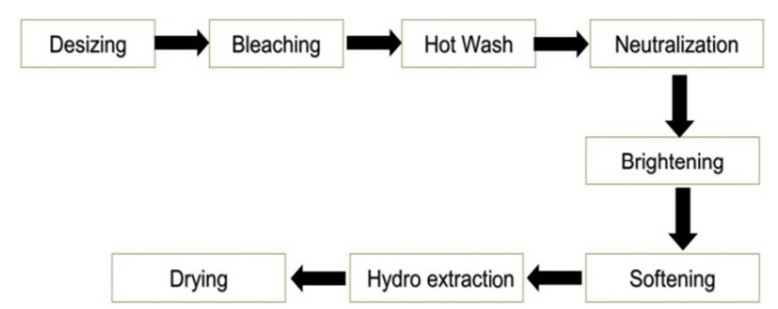

Figure 2. Operational flow diagram of super white washing process.

\subsubsection{Testing of Tensile Strength}

To conduct experimental testing, tensile strength testing was conducted according to ISO 13934 [37].

Testing Method: ISO 13934-2 (grab test)

Testing Condition: Temperature $(20 \pm 2)^{\circ} \mathrm{C}, \quad$ Relative humidity $(65 \pm 2) \%$

Sample size: $200 \mathrm{~mm} \times 100 \mathrm{~mm}$

Apparatus: Titan-Universal Strength Tester, air compressor, computer

\subsubsection{Testing of Tear Strength}

The testing of tear strength of stretch denim fabric samples treated with super white washing process was measured according to the standard of ISO 13937-1 [38].

Sample Conditioning: Conditioning specimen at least 4 hours as per ISO 139.

Testing Condition: Temperature $(20 \pm 2)^{\circ} \mathrm{C}$ and Relative humidity $(65 \pm 4) \%$

Specimen size: As per template

Apparatus: Tearing tester, different capacity load, conditioning rack, calibrated ruler

\subsubsection{Determination of Pilling Resistance}

The determination of pilling resistance of different fabric 
samples treated with super white washing process measured according to ISO 12945-2 [39].

Testing Method: ISO 12945-2

Testing Condition: Temperature $(20 \pm 2)^{\circ} \mathrm{C}$ and Relative humidity $(65 \pm 4) \%$

Specimen size: $125 \mathrm{~mm} \times 125 \mathrm{~mm}$

Apparatus: GSM cutter, electronic balance, scissor, Martindale abrasion and pilling tester

\subsubsection{Testing of Dimensional Stability}

To understand the dimensional stability of the sample according to ISO 23231 [40], an accelerated procedure was carried out for the understanding of dimensional changes of fabrics.

Dimensional Change $(\%)=\{($ Dimension after wash - Original dimension $) \times 100\} /$ Original dimension

Sample Conditioning: Conditioning specimen at least 4 hours as per ISO 139 prior to preparing and measuring.

Testing Condition: Temperature $(20 \pm 2)^{\circ} \mathrm{C}$ and Relative humidity $(65 \pm 4) \%$

Specimen size: As per template

\subsubsection{Measurement of Color Fastness Properties} 43]:

Following color fastness tests were done accordingly [41-

Color fastness to wash (Method: ISO $105 \mathrm{C10}$ )

Color fastness to light (Method: ISO 105 B02)

Color fastness to perspiration (Method: ISO 105 E04)

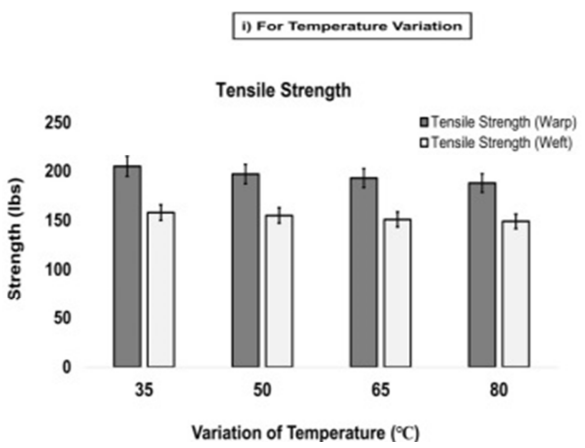

\section{Results and Discussion}

\subsection{Effect of Super White Washing Process Temperature and $\mathrm{OB} A$ Concentration on Tensile Strength for Stretch Denim Fabric}

The following figures represent about the effect of washing process temperature and OBA concentration on tensile strength properties of super white washed stretch denim fabric in both warp and weft direction. These bar diagrams reveal that there was a gradual falling of tensile strength in both the warp and weft direction with the increase of washing process temperature and OBA concentration up to a certain stage. Maximum tensile strength value of warp and weft was observed respectively 205 lbs. and $158 \mathrm{lbs}$. at $35^{\circ} \mathrm{C}$. After a gradual increase of process temperature, it was settling down in $188 \mathrm{lbs}$. and $149 \mathrm{lbs}$. at $80^{\circ} \mathrm{C}$. On the other hand, maximum tensile strength value of warp and weft was depicted respectively about 180 and $143 \mathrm{lbs}$. at $30 \mathrm{~g} / \mathrm{L} \mathrm{OBA}$ concentration. After a gradual increase of OBA concentration, it was settling down to 164 and $134 \mathrm{lbs}$. at $60 \mathrm{~g} / \mathrm{L}$. The reason is that, gradual increase of processing temperature and OBA concentration broken down the $\square \mathrm{OH}$ groups of polymer structure, deformed other strong covalent bonds in fiber molecular structure together with remove the natural coloring materials from the fabrics up to a certain level, which leads to the random drop of tensile strength.

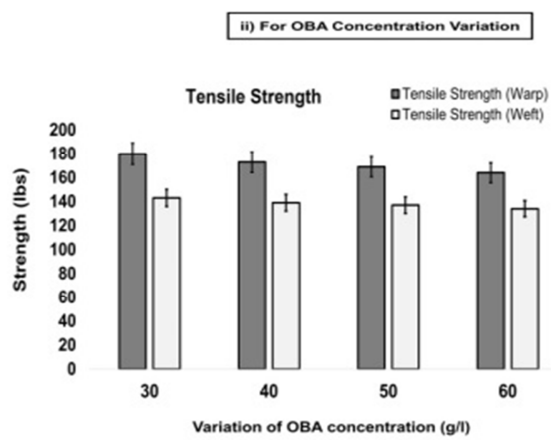

Figure 3. Variation of temperature and OBA concentration on tensile strength of super white washed stretch denim fabric.

\subsection{Effect of Super White Washing Process Temperature and OBA Concentration on Tear Strength for Stretch Denim Fabric}
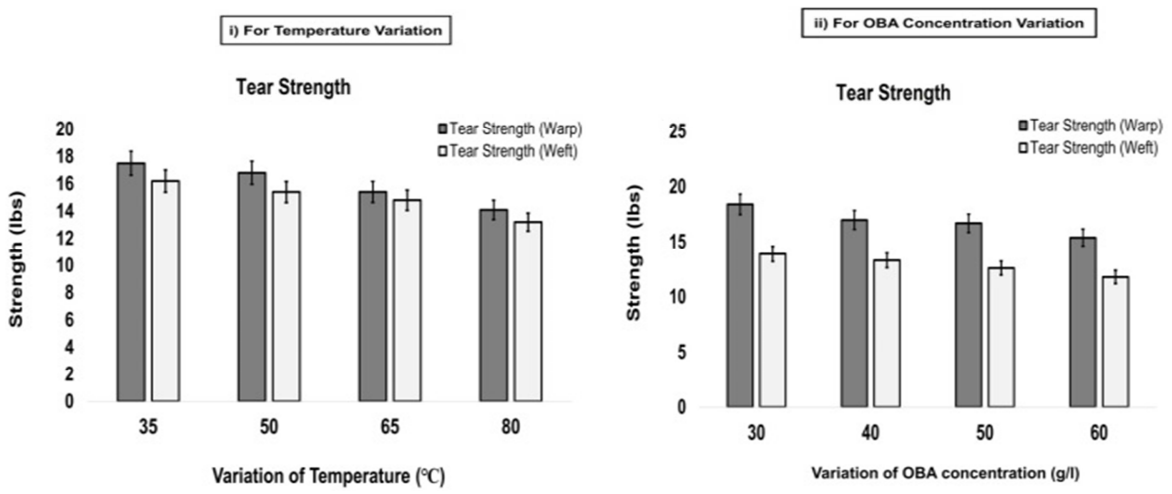

Figure 4. Temperature and $O B A$ concentration variation on tear strength property. 
The above-mentioned figure represents about the effect of temperature on tear strength properties of super white washed stretch denim fabric in both warp and weft direction. These bar diagrams expose that there was a gradual falling of tear strength in both the warp and weft direction with the increase of washing process temperature up to a certain stage. Maximum tear strength value of warp and weft was depicted respectively 17.5 and $16.2 \mathrm{lbs}$. at $35^{\circ} \mathrm{C}$. After a gradual increase of process temperature, it was settling down in 14.1 and $13.2 \mathrm{lbs}$. at $80^{\circ} \mathrm{C}$. On the other hand, maximum tear strength value between warp and weft direction was represented respectively about 18.4 and $13.9 \mathrm{lbs}$. at $30 \mathrm{~g} / \mathrm{L}$. After a gradual increase of OBA concentration, it was settling down to 15.4 and $11.8 \mathrm{lbs}$. at $60 \mathrm{~g} / \mathrm{L}$. From the abovementioned details, it can be assumed that gradual increase of OBA concentration and processing temperature caused more discontinuity between fibers and fiber matrix surface, thus leads to a continuous drop of tear strength up to a certain level.

\subsection{Effect of Super White Washing Process Temperature and $O B A$ Concentration on Dimensional Stability for Stretch Denim Fabric}

Table 1. Variation of temperature on dimensional stability for super white washed stretch denim fabric.

\begin{tabular}{llll}
\hline SL. & \multirow{2}{*}{ Nemperature Variation $\left({ }^{\circ} \mathbf{C}\right)$} & \multicolumn{2}{l}{ Shrinkage $\%$} \\
\cline { 3 - 4 } & & Warp & Weft \\
\hline 1 & 35 & -0.9 & -1.9 \\
2 & 50 & -2.0 & -2.8 \\
3 & 65 & -2.8 & -3.5 \\
4 & 80 & -3.1 & -4.7 \\
\hline
\end{tabular}

Table 2. Variation of $O B A$ concentration on dimensional stability for super white washed stretch denim fabric.

\begin{tabular}{llll}
\hline \multirow{2}{*}{$\begin{array}{llll}\text { SL. } \\
\text { No. }\end{array}$} & $\begin{array}{l}\text { Optical Brightening Agent } \\
\text { (OBA) Concentration }\end{array}$ & \multicolumn{2}{l}{ Shrinkage $\%$} \\
\cline { 3 - 4 } & Variation (g/L) & Warp & Weft \\
\hline 1 & 30 & -3.8 & -4.5 \\
2 & 40 & -3.0 & -3.6 \\
3 & 50 & -2.8 & -3.1 \\
4 & 60 & -2.4 & -2.6 \\
\hline
\end{tabular}

The following tables represent about the effect of

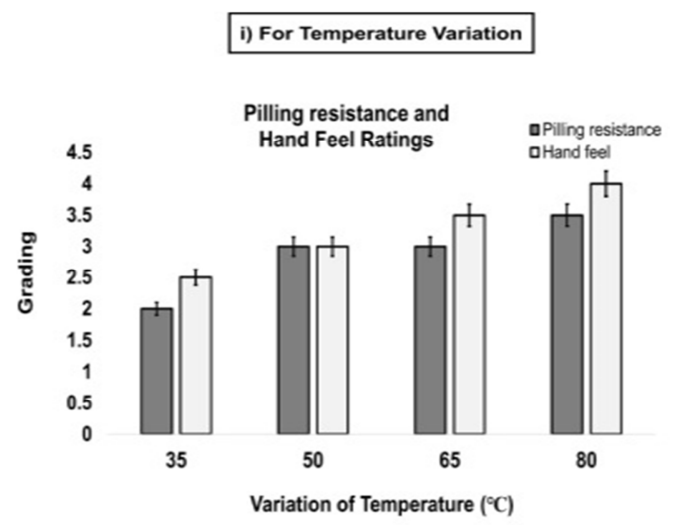

temperature and OBA concentration $(\mathrm{g} / \mathrm{L})$ on dimensional stability of super white washed stretch denim fabric in both warp and weft direction. Minimum shrinkage $\%$ of warp and weft was portrayed respectively $-0.9 \%$ and $-1.9 \%$ at $35^{\circ} \mathrm{C}$. After a gradual increase of process temperature, it was changed to $-3.1 \%$ and $-4.7 \%$ at $80^{\circ} \mathrm{C}$. It can easily be evaluated that weft shrinkage $\%$ for all the samples have quite greater value than that of warp shrinkage \%. In other words, minimum shrinkage $\%$ in warp and weft direction of the fabric was observed respectively about $-3.8 \%$ and $-4.5 \%$ at $30 \mathrm{~g} / \mathrm{L}$. After a gradual increase of OBA concentration, it was changed to $-2.6 \%$ and $-2.4 \%$ respectively at $60 \mathrm{~g} / \mathrm{L}$. Besides the increase of weft shrinkage \% was occurred just because of $97.80 \%$ cotton and $2.20 \%$ spandex composition in fabric, which allowed the fabric to absorb more moisture both in hot temperature and cold air medium. Cotton fiber has a tendency to shrink when it comes in contact to water, whereas spandex fiber shrinks more in hot condition both in the garments washing and drying machine.

\subsection{Effect of Super White Washing Process Temperature and $\mathrm{OBA}$ Concentration on Pilling Resistance and Hand feel Properties for Stretch Denim Fabric}

The following figures reveal that there was a gradual improvement of both the pilling resistance and hand feel ratings with the continuous increase of OBA concentration and processing temperature up to a certain stage. Minimum pilling resistance and hand feel ratings were observed respectively about 2.0 and 2.5 at $35^{\circ} \mathrm{C}$ processing temperature. After a gradual increase of processing temperature, it was moving up within the range of 3-4 and 4 respectively at $80^{\circ} \mathrm{C}$. On the other hand, minimum amount of pilling resistance and hand feel ratings were observed respectively about 2.0 and 2.5 at $30 \mathrm{~g} / \mathrm{L}$ OBA concentration. After a gradual increase of OBA concentration, it was moving up to 3.5 and 4 respectively at $60 \mathrm{~g} / \mathrm{L}$ OBA concentration. Technically pilling not only creates unattractive and fuzzing appearance, but also drops the hand feel rating and serviceability of textile products.

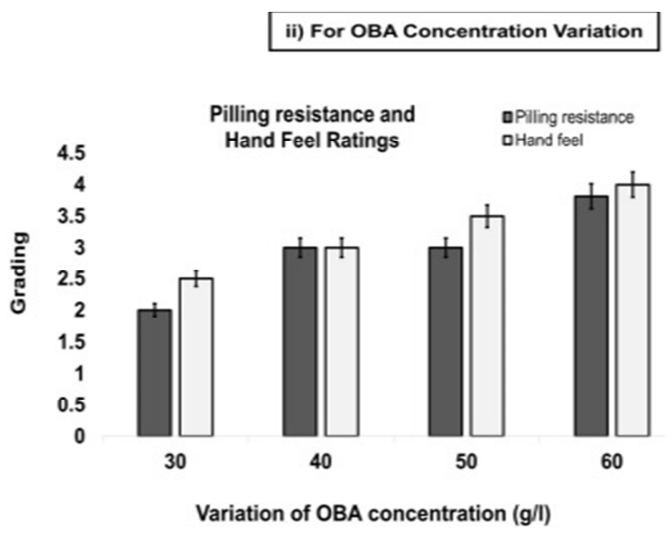

Figure 5. Temperature and $O B A$ concentration variation on pilling resistance and hand feel properties. 


\subsection{Effect of Super White Washing Process Temperature and OBA Concentration on Changes of GSM for Stretch Denim} Fabric
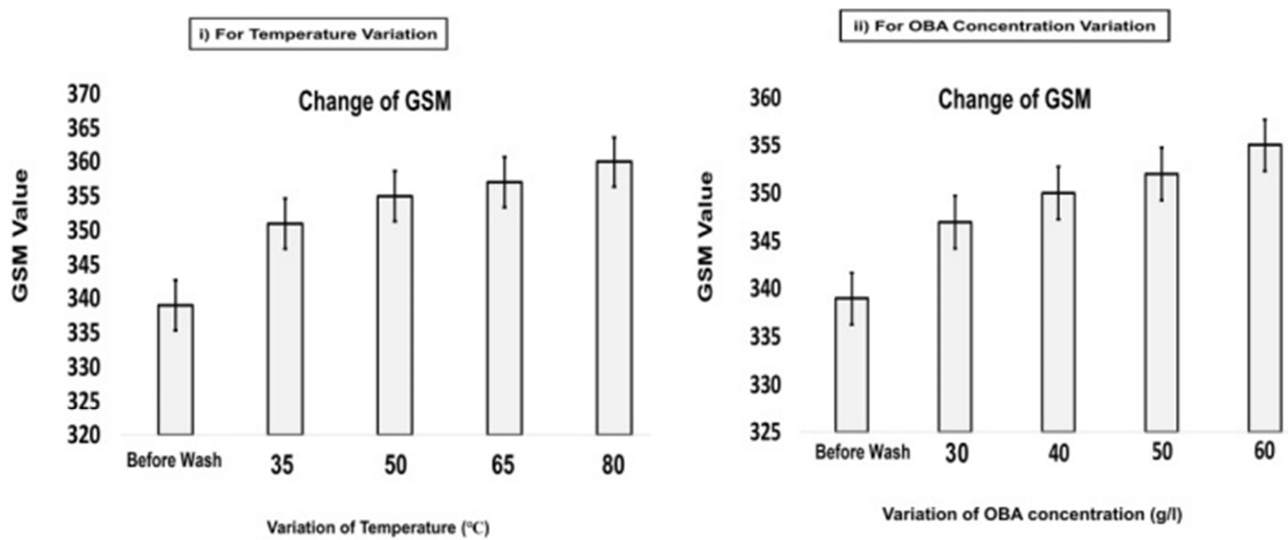

Figure 6. Variation of temperature and OBA concentration on changes of GSM.

The above-mentioned figures illustrate that there was a gradual increase of GSM with respect to the successive increase of OBA concentration and processing temperature. During washing and drying of super white washed stretch denim fabric, the cotton-spandex fabric composition shown a tendency to shrink in both the warp and weft direction, which leads to the rise of GSM value. Minimum GSM value was recorded at $35^{\circ} \mathrm{C}$ along with $30 \mathrm{~g} / \mathrm{L} \mathrm{OBA}$ concentration and maximum GSM value was recorded at $80^{\circ} \mathrm{C}$ along with $60 \mathrm{~g} / \mathrm{L}$.

\subsection{Effect of Washing Process Temperature and OBA Concentration on Color Fastness to Washing for Stretch Denim Fabric}

Table 3. Variation of super white washing process temperature on color fastness to washing for stretch denim fabric.

\begin{tabular}{|c|c|c|c|c|c|c|c|c|}
\hline \multirow{2}{*}{ Sl. No. } & \multirow{2}{*}{$\begin{array}{l}\text { Temperature Variation } \\
\left({ }^{\circ} \mathrm{C}\right)\end{array}$} & \multirow{2}{*}{$\begin{array}{l}\text { Grade (Change } \\
\text { in Color) }\end{array}$} & \multicolumn{6}{|c|}{ Grade (Color Staining on Multi Fiber) } \\
\hline & & & Acetate & Cotton & Nylon & Polyester & Acrylic & Wool \\
\hline 1 & 35 & 3 & 3 & $3-4$ & 3 & 4 & 3 & 3 \\
\hline 2 & 50 & $3-4$ & $3-4$ & 4 & $3-4$ & 3 & 3 & 3 \\
\hline 3 & 65 & 4 & 4 & 4 & 4 & $4-5$ & 4 & 4 \\
\hline 4 & 80 & 4 & 4 & $4-5$ & 4 & 4 & $4-5$ & 4 \\
\hline
\end{tabular}

Table 4. Variation of $O B A$ concentration on color fastness to washing.

\begin{tabular}{|c|c|c|c|c|c|c|c|c|}
\hline \multirow{2}{*}{$\begin{array}{l}\text { Sl. } \\
\text { No. }\end{array}$} & \multirow{2}{*}{$\begin{array}{l}\text { OBA concentration } \\
\text { Variation }(\mathrm{g} / \mathrm{L})\end{array}$} & \multirow{2}{*}{$\begin{array}{l}\text { Grade (Change in } \\
\text { Color) }\end{array}$} & \multicolumn{6}{|c|}{ Grade (Color Staining on Multi Fiber) } \\
\hline & & & Acetate & Cotton & Nylon & Polyester & Acrylic & Wool \\
\hline 1 & 30 & $3-4$ & 3 & $3-4$ & 3 & 4 & $3-4$ & 3 \\
\hline 2 & 40 & 4 & 4 & 4 & $3-4$ & 4 & 4 & $3-4$ \\
\hline 3 & 50 & $4-5$ & 4 & $4-5$ & 4 & $4-5$ & 4 & 4 \\
\hline 4 & 60 & $4-5$ & 4 & $4-5$ & 4 & 4 & $4-5$ & 4 \\
\hline
\end{tabular}

The following tables represent about the effect of washing process temperature and OBA concentration on color fastness to washing for super white washed stretch denim fabric. It was observed that at $35^{\circ} \mathrm{C}$ temperature and $30 \mathrm{~g} / \mathrm{L}$ OBA concentration, super white washed stretch denim fabric illustrated moderate grading for change in color and color staining. After increasing the processing temperature and OBA concentration, grading for change in color and color staining was changed from moderate to good along with good to better respectively for super white washed stretch denim fabric.

\subsection{Effect of Washing Process Temperature and OBA Concentration on Color Fastness to Perspiration for Stretch Denim Fabric}

Table 5. Temperature variation on color fastness to perspiration (acidic).

\begin{tabular}{|c|c|c|c|c|c|c|c|c|}
\hline \multirow{2}{*}{$\begin{array}{l}\text { Sl. } \\
\text { No. }\end{array}$} & \multirow{2}{*}{$\begin{array}{l}\text { Temperature Variation } \\
\left({ }^{\circ} \mathrm{C}\right)\end{array}$} & \multirow{2}{*}{$\begin{array}{l}\text { Grade (Change in } \\
\text { Color) }\end{array}$} & \multicolumn{6}{|c|}{ Grade (Color Staining on Multi Fiber) } \\
\hline & & & Acetate & Cotton & Nylon & Polyester & Acrylic & Wool \\
\hline 1 & 35 & 3 & 3 & $3-4$ & 3 & 4 & 3 & 3 \\
\hline 2 & 50 & $3-4$ & $3-4$ & 4 & $3-4$ & 3 & $3-4$ & 3 \\
\hline 3 & 65 & 4 & 4 & 4 & 4 & $3-4$ & 4 & 4 \\
\hline 4 & 80 & 4 & 4 & 4 & 4 & 4 & $4-5$ & 4 \\
\hline
\end{tabular}


Table 6. Variation of super white washing process temperature on color fastness to perspiration (alkaline).

\begin{tabular}{|c|c|c|c|c|c|c|c|c|}
\hline \multirow{2}{*}{$\begin{array}{l}\text { Sl. } \\
\text { No. }\end{array}$} & \multirow{2}{*}{ Temperature Variation $\left({ }^{\circ} \mathrm{C}\right)$} & \multirow{2}{*}{$\begin{array}{l}\text { Grade (Change } \\
\text { in Color) }\end{array}$} & \multicolumn{6}{|c|}{ Grade (Color Staining on Multi Fiber) } \\
\hline & & & Acetate & Cotton & Nylon & Polyester & Acrylic & Wool \\
\hline 1 & 35 & 3 & 3 & $3-4$ & 3 & 4 & 3 & 3 \\
\hline 2 & 50 & $3-4$ & 3 & 4 & $3-4$ & 3 & 3 & 3 \\
\hline 3 & 65 & 4 & 4 & 4 & 4 & 4 & 4 & 4 \\
\hline 4 & 80 & $4-5$ & 4 & $4-5$ & 4 & 4 & $4-5$ & 4 \\
\hline
\end{tabular}

Table 7. Variation of OBA concentration on color fastness to perspiration (acidic) for super white washed stretch denim fabric.

\begin{tabular}{|c|c|c|c|c|c|c|c|c|}
\hline \multirow{2}{*}{$\begin{array}{l}\text { Sl. } \\
\text { No. }\end{array}$} & \multirow{2}{*}{$\begin{array}{l}\text { OBA Concentration } \\
\text { Variation }(\mathrm{g} / \mathrm{L})\end{array}$} & \multirow{2}{*}{$\begin{array}{l}\text { Grade (Change in } \\
\text { Color) }\end{array}$} & \multicolumn{6}{|c|}{ Grade (Color Staining on Multi Fiber) } \\
\hline & & & Acetate & Cotton & Nylon & Polyester & Acrylic & Wool \\
\hline 1 & 30 & $3-4$ & 3 & $3-4$ & 3 & 4 & 3 & 3 \\
\hline 2 & 40 & $3-4$ & $3-4$ & 4 & $3-4$ & 3 & $3-4$ & 3 \\
\hline 3 & 50 & 4 & 4 & 4 & 4 & 4 & 4 & 4 \\
\hline 4 & 60 & $4-5$ & 4 & $4-5$ & 4 & 4 & $4-5$ & 4 \\
\hline
\end{tabular}

Table 8. OBA concentration variation on color fastness to perspiration (alkaline).

\begin{tabular}{|c|c|c|c|c|c|c|c|c|}
\hline \multirow{2}{*}{$\begin{array}{l}\text { Sl. } \\
\text { No. }\end{array}$} & \multirow{2}{*}{$\begin{array}{l}\text { OBA Concentration } \\
\text { Variation }(\mathrm{g} / \mathrm{L})\end{array}$} & \multirow{2}{*}{$\begin{array}{l}\text { Grade (Change } \\
\text { in Color) }\end{array}$} & \multicolumn{6}{|c|}{ Grade (Color Staining on Multi Fiber) } \\
\hline & & & Acetate & Cotton & Nylon & Polyester & Acrylic & Wool \\
\hline 1 & 30 & $3-4$ & 3 & $3-4$ & 3 & 4 & 3 & 3 \\
\hline 2 & 40 & 4 & $3-4$ & 4 & $3-4$ & 3 & $3-4$ & 3 \\
\hline 3 & 50 & 4 & 4 & 4 & 4 & $3-4$ & 4 & 4 \\
\hline 4 & 60 & $4-5$ & 4 & 4 & 4 & 4 & $4-5$ & 4 \\
\hline
\end{tabular}

The following tables represent about the effect of washing process temperature and OBA concentration on color fastness to perspiration (acidic and alkaline) for super white wash treated stretch denim fabric. It was observed that, in both cases of acidic and alkaline condition at $35^{\circ} \mathrm{C}$ process temperature and $30 \mathrm{~g} / \mathrm{L}$ OBA concentration, super white washed stretch denim fabric illustrated moderate grading for change in color and color staining. After increasing the processing temperature and OBA concentration, grading for change in color and color staining was signified from moderate to good as well as good to better respectively for super white washed stretch denim fabric which implied that no significant change was observed.

\subsection{Effect of Super White Washing Process Temperature and $\mathrm{OBA}$ Concentration on Color Fastness to Light for Stretch Denim Fabric}

Table 9. Variation of processing temperature on color fastness to light.

\begin{tabular}{lll}
\hline $\begin{array}{l}\text { Sl. } \\
\text { No. }\end{array}$ & $\begin{array}{l}\text { Temperature } \\
\text { Variation }\left({ }^{\circ} \mathbf{C}\right)\end{array}$ & $\begin{array}{l}\text { Fastness Rating according to Blue } \\
\text { Wool Standard Grading }\end{array}$ \\
\hline 1 & 35 & $3-4$ \\
2 & 50 & 4 \\
3 & 65 & $4-5$ \\
4 & 80 & 5 \\
\hline
\end{tabular}

Table 10. OBA concentration variation on color fastness to light for super white washed stretch denim fabric.

\begin{tabular}{lll}
\hline $\begin{array}{l}\text { Sl. } \\
\text { No. }\end{array}$ & $\begin{array}{l}\text { OBA Concentration } \\
\text { Variation }(\mathrm{g} / \mathrm{L})\end{array}$ & $\begin{array}{l}\text { Fastness Rating according to } \\
\text { Blue Wool Standard Grading }\end{array}$ \\
\hline 1 & 30 & 4 \\
2 & 40 & 4 \\
3 & 50 & $3-4$ \\
4 & 60 & 3 \\
\hline
\end{tabular}

The above-mentioned tables represent about the effect of washing process temperature and OBA concentration on color fastness to light for super white washed stretch denim fabric. It was observed that, at $35^{\circ} \mathrm{C}$ temperature and $30 \mathrm{~g} / \mathrm{L}$ OBA concentration, super white washed stretch denim fabric illustrated moderate grading. After increasing the processing temperature, grading for color fastness to light became moderate for super white washed stretch denim fabric. On the other hand, gradual decrease of color fastness to light of super white washed stretch denim fabric was observed with respect to the enhancement of OBA concentration. The deep shades of denim surface displayed better resistance against UV light as the electron movement of deep shades was higher than that of light shade. Therefore, the moving electron can easily move to the excited state and did damage to the chromophore group.

\section{Conclusion}

In this research work, variation of washing process temperature $\left(35^{\circ} \mathrm{C}, \quad 50^{\circ} \mathrm{C}, \quad 65^{\circ} \mathrm{C}, \quad 80^{\circ} \mathrm{C}\right)$ and $\mathrm{OBA}$ concentration $(30 \mathrm{~g} / \mathrm{L}, 40 \mathrm{~g} / \mathrm{L}, 50 \mathrm{~g} / \mathrm{L}, 60 \mathrm{~g} / \mathrm{L})$ were utilized on stretch denim fabric processing under super white washing condition to investigate the changes of different properties relating to tensile strength, tear strength, color fastness properties, pilling resistance, hand feel performance and dimensional stability. For tensile strength, tear strength, dimensional stability analysis; stretch denim fabric treated with super white wash at $35^{\circ} \mathrm{C}$ temperature demonstrated better performance rather than other temperature conditions. Similarly, stretch denim fabric treated with super white wash at the condition of $30 \mathrm{~g} / \mathrm{L}$ OBA concentration illustrated better performance rather than other conditions regarding the tensile strength, tear strength, dimensional stability. In the case of dimensional stability, shrinkage \% in both the warp and weft way direction also altered after rising the 
temperature and OBA concentration respectively. In both the cases of processing temperature and OBA concentration, after increasing the temperature from $35^{\circ} \mathrm{C}$ to $80^{\circ} \mathrm{C}$ along with $30 \mathrm{~g} / \mathrm{L}$ to $60 \mathrm{~g} / \mathrm{L}$; super white wash treated stretch denim fabric sample exhibited relatively better performance regarding the pilling resistance, hand feel and color fastness properties. In case of color fastness to light, super white washed stretch denim fabric exhibited moderate performance upon increasing the washing process temperature. Gradual decrease of performance regarding the color fastness to light of super white wash treated stretch denim fabric was also observed with respect to the enhancement of OBA concentration. Stretch denim fabric's GSM also increased successively after raising the processing temperature and OBA concentration. Based upon the findings, manufacturers and technologists will be more cautious about the selection of appropriate washing temperature and OBA concentration for the processing of stretch denim fabric relating to super white washing process.

\section{Compliance with Ethics Requirements}

This article does not contain any studies with human or animal subjects performed by any of the authors.

\section{Conflict of Interest}

The authors have declared no conflict of interest.

\section{Acknowledgements}

The authors gratefully acknowledge the Department of Textile Engineering of Mawlana Bhashani Science and Technology University (MBSTU) for technical support of this work.

\section{References}

[1] Arikan, T., Cavusoglu, B., Alver, Y., Cil, Z. E., Akkaya, S., and Kayaoglu, B. K. (2015). Effects of Different Industrial Washing Processes on Strength and Physical Properties of Denim Fabrics. Tekstil Ve Mühendis, 22 (100), 54-68.

[2] Gusakov, A. V., Sinitsyn, A. P., Berlin, A. G., Markov, A. V., and Ankudimova, N. V. (2000). Surface hydrophobic amino acid residues in cellulase molecules as a structural factor responsible for their high denim-washing performance. Enzyme and microbial technology, 27 (9), 664-671.

[3] Hosen, F., Asif, AKMAH., Hasan, M. Z., Mahmud, S. T., Islam, M. R. (2021). Evaluation of comfort and thermal properties of stretch denim fabric by applying different softeners. Indian Journal of Science and Technology, 14 (8), $752-764$.

[4] Maryan, A. S., and Montazer, M. (2013). A cleaner production of denim garment using one step treatment with amylase/cellulase/laccase. Journal of cleaner production, 57, 320-326.

[5] Kalaoglu, F., and Paul, R. (2015). Finishing of jeans and quality control. Denim, 425-459.

[6] Mangat, M. M., Hussain, T., and Bajzik, V. (2012). Impact of different weft materials and washing treatments on moisture management characteristics of denim. Journal of Engineered Fibers and Fabrics, 7 (1), 38-49.

[7] Roy Choudhury, A. K. (2017). Finishing of denim fabrics. Principles of Textile Finishing, 383-415.

[8] Maryan, A. S., and Montazer, M. (2014). One pot denim washing and finishing using organo-montmorillonite: introducing nano mineral washing and finishing. Textile Research Journal, 85 (1), 91-100.

[9] Hosen, F., Hasan, M. Z., and Asif, A. A. H. (2020). Effect of Different Softeners on Dimensional Stability and Color Fastness Properties of Stretch Denim Fabric. Advances in Applied Sciences, 5 (4), 112-119.

[10] Luiken, A., and Bouwhuis, G. (2015). Recovery and recycling of denim waste. Denim, 527-540.

[11] Kan, C. W., Yuen, C. W. M., and Cheng, C. W. (2012). Color Fading of Indigo-Dyed Cotton Denim Fabric by Laser. Advanced Materials Research, 441, 187-191.

[12] Telli, A., and Babaarslan, O. (2017). The effect of recycled fibers on the washing performance of denim fabrics. The Journal of The Textile Institute, 108 (5), 812-820.

[13] Ansari, I. Z. (2017). Impact of Stone Wash and Acid Wash on the Physical Properties of Denim. International Journal of Engineering Research, 6 (12), 499-501.

[14] Regan, C. (2015). Role of denim and jeans in the fashion industry. Denim, 191-217.

[15] Abdelfattah Halleb, N., Sahnoun, M., and Cheikhrouhou, M. (2015). The effect of washing treatments on the sensory properties of denim fabric. Textile Research Journal, 85 (2), $150-159$.

[16] Anish, R., Rahman, M. S., and Rao, M. (2007). Application of cellulases from an alkalothermophilic Thermomonospora sp. in biopolishing of denims. Biotechnology and Bioengineering, $96(1), 48-56$.

[17] Eryuruk, S. H. (2019). The Effects of Elastane and Finishing Properties on Wicking, Drying and Water Vapor Permeability Properties of Denim Fabrics. International Journal of Clothing Science and Technology, 32 (2), 208-217.

[18] Shaheen, I. M., Mamun, M. A. A., Siddique, M. A. B., Asif, A K. M. A. H. (2016). Effect of Finishing Machine Parameters on Dimensional Stability of Single Lacoste Cotton Knitted Fabric. Advances in Materials, 5 (5), 35-43.

[19] Uzal, N. (2015). Effluent treatment in denim and jeans manufacture. Denim, 541-561.

[20] Khedher, F., Dhouib, S., Msahli, S., and Sakl1, F. (2009). The influence of industrial finishing treatments and their succession on the mechanical properties of denim garment. AUTEX Research Journal, 9 (3), 93-100.

[21] Hasan, M. Z., Asif, A. A. H., Razzaque, A., Hasan, M. R., Sur, S., and Faruque, M. O. (2021). An Experimental Investigation of Different Washing Processes on Various Properties of Stretch Denim Fabric. Journal of Materials Science and Chemical Engineering, 9 (1), 1-15. 
[22] Maryan, A. S., Montazer, M., and Rashidi, A. (2013). Introducing Old-look, Soft Handle, Flame Retardant, and Anti-bacterial Properties to Denim Garments Using Nano Clay. Journal of Engineered Fibers and Fabrics. 8 (4), 68-77.

[23] Becenen, N., and Altun, Ö. (2018). Investigation of the wettability and washing, perspiration and rubbing fastness of denim fabric in the presence of some nano-metal oxides and nano-Ag. The Journal of The Textile Institute, 109 (7), 914919.

[24] Siddique, M. A. B., Asif, A. K. M. A. H., Rashedul, H. K., Anwar, M. T., Saiful, I., Nusrat, N. (2016). Study on the Effect of Dyeing and Finishing Parameters on Cotton Knitted Two Thread Fleece Fabric and 1x1 Rib Fabric. Science Research, 4 (1), 7-10.

[25] Asif, A. K. M. A. and Hasan, M. Z. (2018). Application of Nanotechnology in Modern Textiles: A Review. International Journal of Current Engineering and Technology, 8 (2), 227-231.

[26] Asif, A. K. M. A. H. (2017). An Overview of Sustainability on Apparel Manufacturing Industry in Bangladesh. Science Journal of Energy Engineering, 5 (1), 1-12.

[27] Sarker, P., Asif, A. K. M. A. H, Rahman, M., Islam, M. M. and Rahman, K. H. (2020). Green Dyeing of Silk Fabric with Turmeric Powder Using Tamarind Seed Coat as Mordant. Journal of Materials Science and Chemical Engineering, 8 (2), 65-80.

[28] Juciene, M., Urbelis, V. V., Juchneviciene, Ž., Saceviciene, V. and Dobilaite, V. (2018). The influence of laser treatment and industrial washing on denim fabric tension properties. International Journal of Clothing Science and Technology, 30 (4), 588-596.

[29] Kert, M., Krkoč, V., \& Gorjanc, M. (2019). Influence of Optical Brightening Agent Concentration on Properties of Cotton Fabric Coated with Photochromic Microcapsules Using a Pad-Dry-Cure Process. Polymers, 11 (12), 1919.

[30] Chowdhury, M. A., Butola, B. S., \& Joshi, M. (2013). Application of thermochromic colorants on textiles: temperature dependence of colorimetric properties. Coloration Technology, 129 (3), 232-237.

[31] Billah, S. M. R., Christie, R. M., \& Shamey, R. (2012). Direct coloration of textiles with photochromic dyes. Part3: dyeing of wool with photochromic acid dyes. Coloration Technology, 128 (6), 488-492.
[32] Chowdhury, M. A., Joshi, M., \& Butola, B. S. (2014). Photochromic and thermochromic colorants in textile applications. Journal of Engineered Fibers and Fabrics, 9 (1), 107-123.

[33] Rahman, M., Asif, A. K. M. A. H., Siddiquee, M. A. B. and Rokonuzzaman, M. (2014). Effect of Shade Percentage on Various Properties of Cotton Knitted Fabric Dyed with Reactive Dyes. International Journal of Research in Engineering and Technology, 3 (2), 339-343.

[34] Gorenšek, M., Gorjanc, M., Recelj, P., \& Meden, A. (2008). Parameters influencing dyeability of cotton warp at dip-dyeing for jeans. Textile research journal, 78 (6), 524-531.

[35] Yu, Y., Yuan, J., Wang, Q., Fan, X., Ni, X., Wang, P., and Cui, L. (2013). Cellulase immobilization onto the reversibly soluble methacrylate copolymer for denim washing. Carbohydrate polymers, 95 (2), 675-680.

[36] Tarhan, M., and Sarışık, M. (2009). A comparison among performance characteristics of various denim fading processes. Textile Research Journal, 79 (4), 301-309.

[37] ISO 13934-2: 2014; Textiles - Tensile properties of fabrics - Part 2: Determination of maximum force using the grab method.

[38] ISO 13937-1: 2000; Textiles - Tear properties of fabrics Part 1: Determination of tear force using ballistic pendulum method (Elmendorf).

[39] ISO 12945-2: 2020, Textiles - Determination of fabric propensity to surface pilling, fuzzing or matting - Part 2: Modified Martindale method.

[40] ISO 23231: 2008; Textiles -- Determination of dimensional change of fabrics, Accelerated machine method.

[41] ISO 105-C10: 2006; Textiles -- Tests for color fastness--Part C04: Color fastness to washing: Test 4.

[42] ISO 105-B02: 2014; Textiles -- Tests for color fastness -- Part B02: Color fastness to artificial light: Xenon arc fading lamp test.

[43] ISO 105-E04: 2013; Textiles -- Tests for color fastness -- Part E04: Color fastness to perspiration. 